\title{
Mission, Reunion and the Anglican Communion: The 'Appeal to All Christian People' and approaches to ecclesial unity at the 1920 Lambeth Conference
}

\author{
Charlotte Methuen \\ Professor of Ecclesiastical History, School of Critical Studies (Theology and \\ Religious Studies), University of Glasgow, Glasgow, Scotland \\ charlotte.methuen@glasgow.ac.uk
}

\begin{abstract}
This article explores the understanding of unity articulated in the 'Appeal to all Christian People' issued by the 1920 Lambeth Conference of Anglican bishops. It first examines the expression of the Appeal's vision in terms of organic unity and mutual recognition, the way that this developed through the drafting process and how this vision related to later Anglican approaches to unity. It then explores the relationship of the Appeal to the Lambeth Quadrilateral of 1888, particularly with respect to the episcopate, arguing that the Appeal took an ambiguous approach to episcopacy which was in tension with the language of mutual recognition. Finally, acknowledging that the overarching theme of the 1920 Lambeth Conference was 'fellowship', the article considers the Appeal's vision of unity in the context of the approach to unity taken by the 1920 Lambeth Conference more widely, including the Conference's other ecumenical resolutions, and its resolutions on mission and the Anglican Communion and the bishops' Encyclical Letter, particularly its approach to international relations. The article concludes that, while the vision of organic unity that was articulated in the Appeal was reflected in the conference's resolutions on mission, in other aspects of its work the 1920 Lambeth Conference tended to take a federal approach to unity and fellowship and was thus not fully consistent.
\end{abstract}

\section{Keywords}

Anglican Communion - Lambeth Conference 1920 - Appeal to All Christian People Lambeth Quadrilateral - Christian unity - episcopacy - Bishop George Bell - Bishop Hensley Henson - Archbishop Cosmo Gordon Lang - Bishop Frank Weston 
The* 1920 Lambeth Conference is most closely associated with the 'Appeal to All Christian People', the exhortation to unity between the churches which was proposed by the Conference committee on 'Reunion'. Mary Tanner has observed that the Appeal emerged from a context in which 'talk of reunion had thrown up different models: mutual recognition, organic union, federation, absorption, submission.' In the Appeal, 'the bishops were clear that unity could never mean uniformity or vague federation'.2 Rather, they affirmed that 'God wills fellowship' and that this fellowship should be manifested 'in an outward, visible, and united society, holding one faith, having its own recognized officers, using God-given means of grace, and inspiring all its members to the world-wide service of the Kingdom of God. ${ }^{3}$ The bishops explicitly rejected absorption as an approach to unity, emphasising in the conclusion of the Appeal, 'we do not ask that any one Communion should consent to be absorbed into another'. Instead, they understood this unity as characterised by a 'a rich diversity of life and devotion', brought together by 'Christian Communions now separated from one another', which 'would retain much that has long been distinctive in their methods of worship and service. ${ }^{5}$ Drafted in a period when the ecumenical movement was just beginning to take shape, it should not be surprising that the Appeal does not exemplify only one approach to or understanding of unity. What is striking, however, is that there are aspects of the Appeal that resonate with the modern approach of receptive ecumenism, ${ }^{6}$ while

* The author is grateful to Paul Avis for his invitation to contribute to this issue of Ecclesiology, and to him and Dan D. Cruickshank for their comments and suggestions.

1 Mary Tanner, 'The Ecumenical Dimension of the Lambeth Conference', in Paul Avis and Benjamin Guyer (eds), The Lambeth Conference: History, Theology, Polity and Purpose (London: Bloomsbury T\&T Clark, 2018), pp. $35^{8-387}$, at p. 366 . The list of approaches to unity is drawn from the Encyclical Letter in Conference of Bishops of the Anglican Communion holden at Lambeth Palace, July 5 to August 7, 1920, Encyclical Letter from the Bishops with the Resolutions and Reports, 2nd edition (London: SPCK, 1920) [hereinafter LC 1920 Encyclical], p. 11.

2 Tanner, 'The Ecumenical Dimension of the Lambeth Conference', p. 366.

3 'Appeal to All Christian People', Lambeth Conference (hereinafter LC) 1920, Resolution 9.I. The Resolutions can be found in Conference of Bishops of the Anglican Communion holden at Lambeth Palace, July 5 to August 7, 1920, Encyclical Letter from the Bishops with the Resolutions and Reports, pp. 25-47; they are available online at https://www.anglicancommunion.org/ resources/document-library/lambeth-conference/1920/lambeth-conference-archives -1920-index?year=1920 (accessed 8 March 2020).

4 'Appeal to All Christian People', LC 1920, Resolution 9.IX.

5 'Appeal to All Christian People', LC 1920, Resolution 9.IV.

6 For an introduction to receptive ecumenism, see Paul D. Murray, 'Receptive Ecumenism and Catholic Learning: Establishing the Agenda', International Journal for the Study of the Christian Church 7 (2007), pp. 279-301. An Anglican approach is offered by Callan Slipper, Enriched by the Other: A spiritual guide to receptive ecumenism (Grove Books 139; Cambridge: Grove Books, 2016). 
other clauses appear to speak the language of the approaches of reconciled diversity, unity in diversity, conciliar fellowship, or koinonia. ${ }^{7}$ The Appeal thus presages a range of fruitful ecumenical approaches that underpinned the achievements of the post-war ecumenical movement and shaped ecumenical thinking in the early the twenty-first century.

This article explores the understanding of unity articulated in the 1920 Lambeth Appeal, looking, as a first step, at the articulation of its vision and the way that this developed through the drafting process and relating this vision to later Anglican approaches to unity. In a second step, it explores the relationship of the Appeal to the Lambeth Quadrilateral, particularly with respect to the episcopate, asking what light this sheds on the Appeal's approach to unity. Finally, recognising that the overarching theme of the 1920 Lambeth Conference was fellowship, this article considers the Appeal's vision of unity in the context of work of the other committees of the 1920 Lambeth Conference, making reference also to the Conference's other ecumenical resolutions and considering the understanding of unity expressed in the Conference's resolutions on mission and on the Anglican Communion. To what extent do these different discussions of ecclesial unity - which emerged from separate committees and subcommittees of the conference before being approved in plenary - articulate a understanding which is coherent with that found in the Appeal?

\section{The Vision of Unity in the 'Appeal to All Christian People'}

\section{a Organic Union}

Of the various categories introduced by Mary Tanner in the article cited above (mutual recognition, organic union, federation, absorption, submission), there can be little doubt that the vision of unity that was articulated by the Anglican bishops at the 1920 Lambeth conference held together aspects of mutual recognition with an aim of organic union. This is an important finding, and it can be seen from the drafts of the Appeal that it was not a foregone conclusion. As I have shown elsewhere, ${ }^{8}$ in articulating its vision, the drafters of the Appeal drew on a range of already existing ecumenical texts,

7 See for a brief but useful discussion of these terms, Brendan Leahy, 'Where is Ecumenism at Today?', The Furrow 6o (2009), pp. 25-31.

8 Charlotte Methuen, "An adventure of goodwill and still more of faith": The "Appeal to all Christian People" (1920) in its ecumenical context', in Christopher Wells and Jeremy Worthen (eds), 'God Wills Fellowship': The 1920 Lambeth Conference and the Ecumenical Vocation of Anglicanism (Eugene, OR: Wipf \& Stock, forthcoming 2020). 
particularly those collected by George Bell, later Dean of Canterbury and Bishop of Chichester, but then Chaplain to the Archbishop of Canterbury, in Documents bearing on the problem of Christian unity and fellowship, 1916-1920 that he prepared for the 1920 Lambeth Conference. ${ }^{9}$ Of particular importance were the 1918 Kikuyu proposals for the union of the East African mission societies, the South India proposals of 1919, the Interim reports of the English sub-committee of the World Conference on Faith and Order, proposals for a Concordat between the Protestant Episcopal Church of the USA and the Congregational Church, and a series of discussions with English Free Churches. Elements of these earlier discussions and proposals fed into the Appeal, bringing with them different understandings of unity and of the aims of what was then known as Reunion. ${ }^{10}$ Not included in Bell's collection, but also influential, was the 'The Patriarchal and Synodical Encyclical of 1920: To the Churches of Christ Everywhere' issued by the Patriarchate of Constantinople in January 1920. ${ }^{11}$

Despite this range of influences, the Lambeth bishops articulated a clear understanding of their ultimate aim. In the preamble to the Appeal, they first affirmed: 'We acknowledge all those who believe in our Lord Jesus Christ, and have been baptized into the name of the Holy Trinity, as sharing with us

9 G. K. A. Bell (ed.), Documents bearing on the problem of Christian unity and fellowship, 1916-1920 (London: SPCK, 1920). Hereinafter Documents (1916-20).

10 David van Krieken Vannerley highlights the importance of the 1918 Kikuyu proposals and the Church of South India proposals: see 'The Church's One Foundation:The Anglican Origins and Ecclesiological Significance of the 1920 Lambeth Appeal to All Christian People' (unpublished PhD Thesis, Canterbury Christ Church University, 2015), pp. 152-153. Jaako Rusama claims that, 'It is obvious that Bishop Headlam's Bampton Lectures in 1920, The Doctrine of the Church and Reunion, had an influence on the Appeal': 'George Bell and the Promotion of Anglican Lutheran Relations', in Andrew Chandler (ed.), The Church and Humanity: The Life and Work of George Bell 1883-1958 (Aldershot: Ashgate, 2012), pp. 195-208, at p. 197. However, although Headlam's Bampton Lectures - and specifically his view of mutual recognition of orders - were mentioned in an intervention by James Palmer, Bishop of Bombay, during the opening discussion of the Committee on Reunion on 12 July (cf. Lambeth Palace Library [hereinafter LPL] Bell Papers 255, fol. 15v), Headlam was not a member of the Committee for Reunion and there is no evidence from the extant accounts of proceedings that he was involved in the process of drafting the appeal; for those who were, see Charlotte Methuen, 'Lambeth 1920: The Appeal To All Christian People - An account by G. K. A. Bell and the redactions of the Appeal', in Melanie Barber, Gabriel Sewell and Stephen Taylor (eds), From the Reformation to the Permissive Society: A Miscellany in Celebration of the 4ooth Anniversary of Lambeth Palace Library (Woodbridge: Boydell, 2010). Cf. also eadem, 'The Making of "An Appeal to All Christian People" at the 1920 Lambeth Conference', in Avis and Guyer (eds), The Lambeth Conference, pp. 107-131.

11 For the text see http://orthodox-voice.blogspot.com/2011/o4/patriarchal-and-synodical -encyclical-of_26.html (accessed 11 March 2020). The enclyclical took a loosely federal approach, arguing for 'a friendship and kindly disposition' between the churches. 
membership in the universal Church of Christ which is his Body.'12 On the basis of that recognition, they explained:

We believe that the Holy Spirit has called us in a very solemn and special manner to associate ourselves in penitence and prayer with all those who deplore the divisions of Christian people, and are inspired by the vision and hope of a visible unity of the whole Church. ${ }^{13}$

The bishops then stated their 'vision and hope':

The vision which rises before us is that of a Church, genuinely Catholic, loyal to all truth, and gathering into its fellowship all 'who profess and call themselves Christians,' within whose visible unity all the treasures of faith and order, bequeathed as a heritage by the past to the present, shall be possessed in common, and made serviceable to the whole Body of Christ. Within this unity Christian Communions now separated from one another would retain much that has long been distinctive in their methods of worship and service. It is through a rich diversity of life and devotion that the unity of the whole fellowship will be fulfilled. ${ }^{14}$

Moreover, in the opening summary (cited in the first paragraph of this article), the Lambeth bishops expressed their conviction that:

it is God's purpose to manifest this fellowship, so far as this world is concerned, in an outward, visible, and united society, holding one faith, having its own recognized officers, using God-given means of grace, and inspiring all its members to the world-wide service of the Kingdom of God. ${ }^{15}$

These formulations of the Lambeth bishops' vision in the Appeal all suggest that they understood the 'visible unity' sought by the Appeal to take the form of organic union, with all Christians brought together into a united church with a recognised ministry and an agreed doctrinal basis.

However, the focus on the 'outward, visible, and united society' in these articulations of the bishops' vision for unity in the final text of the Appeal

\footnotetext{
12 'Appeal to All Christian People', LC 1920, Resolution 9, preamble.

13 Ibid.

14 'Appeal to All Christian People', LC 1920, Resolution 9.IV.

15 'Appeal to All Christian People', LC 1920, Resolution 9.I.
} 
represents a change from that formulated in an earlier draft of the Appeal, in which they had taken an approach that might be regarded as federal:

We have a vision of many groups retaining their own systems while combined in one organic fellowship, in which all the treasures of faith and order, possessed at present separately, may find full scope and be available for the whole body. ${ }^{16}$

The bishops' understanding of these 'systems' was more closely defined in another, subsequent, redaction of the Appeal:

The vision which rises before us is that of a truly Catholic Church within which many groups would retain their characteristic systems of life and worship in one organic, visible friendship, and all the treasures of faith and order, possessed at presently separately, would find full scope, and be available for the whole body. ${ }^{17}$

In these earlier drafts, the stipulation 'retaining their own [characteristic] systems' echoed the response of Frank Weston, Bishop of Zanzibar, to the 1918 Kikuyu proposals, in which he proposed that 'non-episcopal bodies accepting episcopacy would remain in full exercise of their own constitution. ${ }^{18}$ However, the final version of the Appeal moved away from the language of 'characteristic systems' to language of 'distinctiveness', affirming that 'within this unity Christian Communions now separated from one another would retain much that has long been distinctive in their methods of worship and service.' ${ }^{19}$ Moreover, the language of 'organic fellowship' or 'organic, visible friendship' used in the

16 Methuen, 'Lambeth 1920', pp. 521-564, at p. 553 (Text B). Compare also Vannerley, 'The Church's One Foundation', p. 240 (Texts D3, D4, D5). Unfortunately, Vannerley was not aware of my work on the Appeal when he undertook his research. Between us, Vannerley and I found different sets of redactions of the Appeal: we both used the redactions included in the minutes book: LPL, LC 115, 'Committee A, relations to reunion with other churches' (minutes book); I also used redactions found in LPL LC 117, 'Committee for reunion with non-episcopal churches' (minutes book) and in the Douglas papers, whilst Vannerley used a set found in LPL LC 141, the LC reports book. We also identified the drafts differently: I identified three drafts [A, B, C] and the final version, whilst Vannerley labelled the eight redactions available to him D1-D8. My A drafts correspond roughly to Vannerley's D1 and D2; my B drafts to his $\mathrm{D}_{3}$ and $\mathrm{D}_{4}$. Vannerley does not have an equivalent of my C draft. My C2 corresponds to Vannerley's $\mathrm{D}_{5}$ draft. For the chronology of the drafting of the Appeal, see Methuen, 'Lambeth 1920', pp. 563-564.

17 Methuen, 'Lambeth 1920', p. 553 (Text C). This redaction of the Appeal was not considered by Vannerley.

18 Documents (1916-1920), p. 46.

19 'Appeal to All Christian People', LC 1920, Resolution 9.IV. 
earlier redactions of the Appeal suggests a looser structure that that implied by 'outward, visible, and united society', the formulation used in the final version.

These developments reflect an attempt to bring together the different understandings of unity proposed by the bishops at the first debate of the Reunion Committee on 12 July, on which George Bell took extensive notes. This focused on a catalogue of four questions, the first being 'What idea of unity do we have?'20 Several of the bishops' responses to this question focused on the distinction between federal and organic unity. Their approach can be summarised by a written submission from Frederic Chase, Bishop of Ely: 'We desire organic, want visible unity without uniformity, but as a road w[oul]d be ready to agree to some form of federation. ${ }^{21}$ Charles D'Arcy, Archbishop of Armagh, protested that the understanding of unity as '[a] federation of diversely organised churches each recognising order of others, with a superior Board for reference and Appeal' was 'not a sufficient ideal.22 James Palmer, Bishop of Bombay, suggested that 'federal unity is [the] type favoured by churches in great areas. But in [a] small area organic unity [should be the goal]. ${ }^{23}$ Herbert Hensley Henson, recently appointed Bishop of Durham, was impatient of such distinctions, proposing that the 'ideal of unity - Catholic Church - [was] all who profess \& call themselves Christians', and that it was 'indeterminate whether this involves one visible union'. ${ }^{24}$ Frank Weston, Bishop of Zanzibar, proposed a view which, although he named it organic, seems closer to a federal approach:

The union we desire to see is one of organic life centred on authority expressed in a college of bishops linking with past \& pointing to future. We desire union of faith - Scripture and Nic[ene] Creed. Thirdly a variety of life with Baptism (\& laying on of hands) \& Holy Com[munion]. It should be inclusive, each group maintaining its own method of selfcontrol, \& worship, and holding communion with every other group

The other three questions, which will be discussed below, were: 'What do we consider to be the necessary conditions of Catholic unity as regards Faith, Sacraments and Ministry? What do we regard as the sufficient principle justifying any claim that the ministry of a united church should be based upon episcopal ordination? What attitude ought we to take as to the "validity" of the orders and sacraments of the nonepiscopal churches?' The questions are found at LPL LC 115, fol. 7; compare Vannerley, 'The Church's One Foundation', p. 134. For Bell's notes on the discussions of the reunion committee fol. 14-69, see LPL Bell Papers 255, fols 14-69.

21 LPL, Bell Papers 255, fol. 14r.

22 LPL, Bell Papers 255, fol. 14v.

23 LPL, Bell Papers 255, fol. 15r.

24 LPL, Bell Papers 255, fol. $17 \mathrm{~V}$. 
either unconditionally or conditioned by whatever rules necessary to keep the congregations satisfied. ${ }^{25}$

The tension between the federal and organic approaches remained unresolved in this debate, and as has already been seen, to some extent it remained unresolved also in the final text of the Appeal. ${ }^{26}$

In its articulation of the vision of unity, however, the final version of the Appeal had certainly moved towards an affirmation of the goal of organic unity, taking a line that reflected more closely the proposals for a United Church of South India, than Zanzibar's response to the Kikuyu proposals. The South India proposals defined the aim of church reunion to be a united church, established 'not on any basis of compromise but on one of comprehension, where each body shall contribute its treasures and tradition to the enrichment of the whole. ${ }^{27}$ Emphasising as it did that 'it is through a rich diversity of life and devotion that the unity of the whole fellowship will be fulfilled, ${ }^{28}$ the vision of unity articulated in the Appeal resonated deeply with this approach. This was reflected in the affirmative approach it took to other churches.

\section{b Mutual Recognition of Churches}

In formulating their vision of unity in this way, the Lambeth bishops also implicitly recognised and affirmed the existence of other churches. In its expounding of the situation of divided Christendom, and its expression of regret for that situation, the Appeal recognised that division had brought about the existence of 'different groups, each one keeping to itself gifts that rightly belong to the whole fellowship, and tending to live its own life apart from the rest. ${ }^{29}$ While the existence of division and the separation between these different groups were to be deplored, the giftedness of these different groups - that is, of the different churches - was thereby affirmed. The Encyclical emphasised

25 LPL, Bell Papers, 255, fol. 16r. The final clause in Bell's notes reads 'conditioned by whatever rules not necessary to keep the congregations dissatisfied', but in the context this cannot correctly replicate Weston's intervention. As will be seen in section II below, the structure of Weston's approach was reflected in the Appeal's assertion of the basis of agreement.

26 Palmer, who acted as secretary to the sub-committee on reunion with non-episcopal churches, suggested in his intervention that this sub-committee would focus on organic unity, while that considering reunion with episcopal churches would discuss federal unity; however it does not seem that this was how the work of the committees developed: see LPL, Bell Papers 255, fol. 15r.

27 Documents (1916-1920), p. 28.

28 'Appeal to All Christian People', LC 1920, Resolution 9.IV.

29 'Appeal to All Christian People', LC 1920, Resolution 9.II. 
that this recognition not only underpinned the Appeal but also constituted the originality of its approach:

Now we see that those elements of truth about which differences have arisen are essential to the fullness of the witness of the whole Church. We have no need to belittle what is distinctive in our own interpretation of Christian life: we believe that it is something precious which we hold in trust for the common good. We desire that others should share in our heritage and our blessings, as we wish to share in theirs. It is not by reducing the different groups of Christians to uniformity, but by rightly using their diversity, that the Church can become all things to all men. ${ }^{30}$

This ideal could not be realised if these groups are content to remain in separation from one another or to be joined together only in some vague federation'. Rather, 'Their value for the fullness of Christian life, truth, and witness can only be realized if they are united in the fellowship of one visible society whose members are bound together by the ties of a common faith, common sacraments, and a common ministry.'31 Fundamental to this approach was the affirmation of the different gifts held within other churches, and thus the recognition of other churches as churches.

As already seen, the preamble of the Appeal asserted that 'membership in the universal Church of Christ which is his Body' was held by and shared with 'all those who believe in our Lord Jesus Christ, and have been baptized into the name of the Holy Trinity' (as proposed by Hensley Henson in the subcommittee debate). However, a categorical distinction was made amongst churches, for the Anglican Communion divided the churches to which it related into two different groups: 'episcopal' and 'non-episcopal'. ${ }^{32}$ Indeed, the Lambeth Conference's Committee on Reunion met in two sub-committees: for relations with the episcopal and non-episcopal churches respectively. The final text of the Appeal (which emerged from the latter sub-committee) replicated this structure by differentiating between 'the other ancient episcopal Communions in East and West, to whom ours is bound by many ties of common faith and tradition' and 'the great non-episcopal Communions, standing for rich elements of truth, liberty and life which might otherwise have been obscured or

3o LC 1920 Encyclical, p. 12.

31 LC 1920 Encyclical, p. 12.

32 I recognise the problematic nature of defining churches in this way, and will return to this point in section II.b, but it is the language used at the time and for simplicity's sake I shall use it here. 
neglected. ${ }^{33}$ This division reflected the Anglican affirmation of the fundamental importance of the episcopate for church unity, articulated in the 1888 Chicago-Lambeth Quadrilateral (and discussed at II.b below), but the Appeal's formulation of it includes an important affirmation that the non-episcopal traditions are also characterised by 'rich elements of truth, liberty and life'.

The Appeal's formulation of the difference between the episcopal and nonepiscopal communions was a late addition in the drafting process. ${ }^{34}$ The first draft of the Appeal included a strong confirmation of the spiritual value of the ministry and sacraments of non-episcopal churches: the bishops 'gladly acknowledge, that God has been pleased to confer gifts of His Holy Spirit upon the Ministry of Churches which have not accepted Episcopal ordination, and to use the Sacraments administered in them as effectual means of grace.'35 This passage did not appear in the subsequent redactions of the Appeal, but reemerged in revised form in the final text, which affirmed 'the spiritual reality of the ministries of those Communions which do not possess the episcopate', recognising them as having been 'manifestly blessed and owned by the Holy Spirit as effective means of grace. ${ }^{36}$ In contrast, the second draft of the Appeal sought to align the Anglican Communion with the episcopal communions: 'We confidently claim a place by the side of the ancient episcopal communions of East and West, awaiting hopefully such mutual re-union as will again unite us in completeness of fellowship. ${ }^{37}$ This phrasing disappeared in the final text, to be replaced by the affirmation of the 'many ties of common faith and tradition' which bound the Anglican Communion to the other episcopal communions. The phrasing in the second redaction, and the distinction made between the episcopal and non-episcopal communions in the final text, both point towards an underlying conception of ecclesial hierarchy in which episcopal churches are superior to non-episcopal churches. Anglican claims to a

33 'Appeal to All Christian People', LC 1920, Resolution 9.II.

34 It first appeared in the draft circulated on 23 July 1920: Methuen, 'Lambeth 1920', pp. 551552 (Text C).

35 Methuen, 'Lambeth 1920', pp. 555-556 (Text A); Vannerley, 'The Church's One Foundation', p. 241 (Texts D1 and D2). A almost identical formulation was included in the preamble to a set of draft Resolutions proposed by Cosmo Lang, Archbishop of York and chairman of the Committee, which were concerned with the practicalities of Reunion: 'We acknowledge the Ministry of Non-Episcopal Churches as a Ministry possessing the gifts of the Spirit, and the Sacraments administered by them as effectual means of grace': Methuen, 'Lambeth 1920', p. 560 (Text F).

36 Methuen, 'Lambeth 1920', p. 555 (Final Text); Vannerley, 'The Church's One Foundation', p. 241 (Text D6). Compare 'Appeal to All Christian People', LC 1920, Resolution 9.VII.

Methuen, 'Lambeth 1920', p. 555 (Text B); Vannerley, 'The Church's One Foundation', p. 241 (Texts $\left.\mathrm{D}_{3}, \mathrm{D}_{4}, \mathrm{D}_{5}\right)$. 
place amongst the ancient episcopal communions were more muted in the final version of the Appeal, although the identification of episcopacy as 'the best instrument for maintaining the unity and continuity of the Church' tended to support the sense of hierarchy. ${ }^{38}$ Nonetheless, the final text of the Appeal explicitly affirmed the movement of the Holy Spirit in the members of both the episcopal and the non-episcopal Communions. The inclusion of this affirmation meant that, at least implicitly, the Appeal recognised the members of both sets of Communions, episcopal and non-episcopal, as churches.

In taking this line, the Appeal avoided considering divided Christendom through the lens of what Matthew Kemp has termed the inadequate solution [of] triumphalism, in which one group of Christians claims that they, and they alone, constitute the one church, and all others somehow fall short'. ${ }^{39}$ The first draft of the Appeal was explicit that the bishops' view of division was not that all should reconciled with the Anglican churches, although it also hints that they were aware of, and, at least to some extent, swayed by, this way of thinking:

Our aim, therefore, is not merely or mainly ['merely or mainly' subsequently amended to 'primarily'] that some of the Churches, into which the one Church has been split up, should be united with ours, but that all should co-operate in manifesting in one visible body the fullness of the diverse gifts of the Spirit. ${ }^{40}$

That was to say, as the first draft explained, in words which were not included in the final Appeal, but which suggest the ecclesiological understanding that underpinned it, that:

our ideal is neither the absorption of these churches into one uniform system, not their alliance in a loose federation, but a living fellowship in which the various gifts and graces bestowed by God upon each shall be no longer kept in separateness, but used and enjoyed for the enrichment of the whole body. ${ }^{41}$

38 'Appeal to All Christian People', LC 1920, Resolution 9.VII.

39 Matthew Kemp, 'Toward a Theology of Church Division: Carl Braaten and Ephraim Radner in Dialogue', Ecclesiology 15.2 (2019), pp. 152-169, at p. $15^{2}$.

40 Methuen, 'Lambeth 1920', p. 553 (Text A); Vannerley, 'The Church's One Foundation', p. 239 (Texts D1 and D2).

41 Methuen, 'Lambeth 1920', p. 553 (Text A); Vannerley ‘The Church's One Foundation', p. 239 (Text D1) and p. 240 (Text D2). 
In the process of drafting the Appeal, therefore, the Lambeth bishops seem to have recognised the importance to the goal of attaining unity of recognising each other's gifts and being prepared to receive those gifts from one another. There are parallels here to one of the ecclesiological shifts within Roman Catholicism after Vatican II which led to the recognition that underlies the approach of receptive ecumenism:

whilst the Catholic Church lacks none of the essential marks of the Church of Christ these marks cannot ... be regarded as being present either exclusively or perfectly within Roman Catholicism. On the contrary, the Catholic Church, itself always in need of purification, semper purificanda, can properly appreciate and receive from the aspects of catholicity present in other traditions. ${ }^{42}$

The Lambeth Appeal did not articulate the method of receptive ecumenism, which has emerged in the context of twenty-first-century Roman Catholicism; in particular the Appeal's affirmation that all churches have their own distinctive gifts is not equivalent to the perspective that every church needs - along with its members - to become more sharply aware of [its] own respective lacks, needs and sticking points and [its] inability to tend to them of [its] own resources without recourse to the particular gifts of other traditions. ${ }^{\prime 43}$ Nonetheless, the presuppositions of receptive ecumenism are intrinsic to the Appeal.

In valuing the gifts of all churches, the Lambeth bishops were taking forward the attitude towards other churches that had been adopted by the Archbishop of Canterbury, Randall Davidson, in his address to the World Missionary Conference at Edinburgh in 1910. As Keith Clements observes, in that address, Davidson 'did not talk about Christian unity of cooperation, but embodied it in addressing his audience as "brothers and sisters in Christ". ${ }^{4}$ Moreover, in adopting this line, the Appeal aligned itself with the approach taken by those preparing for the World Conference on Faith and Order (which took place in 1927), which treated all those involved as equal partners. ${ }^{45}$ The World Council

\footnotetext{
42 Murray, 'Receptive Ecumenism', p. 288.

43 Ibid., p. 291.

44 Keith W. Clements, Faith on the Frontier: A life of J. H. Oldham (Edinburgh/Geneva: T\&T Clark/wCc Publications, 1999), p. 90.

45 This is emphasised in the preparatory document put out by the World Conference for the consideration of questions touching Faith and Order, The Object and Method of Conference (n.pl.: Commission of the Protestant Episcopal Church 1915), for instance at p. 23: 'We meet to learn the real value of other men's rules, and concurrently of our own.' For
} 
of Churches, after it came into being in 1948, was not able to affirm this understanding explicitly, since, as Erin M. Brigham points out, 'Orthodox ecclesiology complicates the idea of "mutual recognition" - acknowledging the ecclesial status of other churches. ${ }^{46}$ However, in the latter part of the twentieth century, this approach would be adopted by several Anglican churches in bilateral agreements such as the Meissen, Fetter Lane, Reuilly and Porvoo Agreements, the Anglican-Methodist Covenant, Called to Common Mission, and the Waterloo and Columba Declarations, all of which begin with the mutual acknowledgement of the dialogue partners as churches. Foundational to such agreements is a form of mutual ecclesial recognition. As the Meissen Agreement (1988) between the Church of England and the EKD (Protestant Church of Germany) puts it, 'We acknowledge one another's churches as churches belonging to the One, Holy, Catholic and Apostolic Church of Jesus Christ and truly participating in the apostolic mission of the whole people of God.'47 The language of the Meissen Agreement is more focused and more explicitly ecclesiological, but the conviction it re-affirms is a re-articulation of that expressed in the Appeal: ecumenical dialogue, or ecumenical agreement, encourages churches of Jesus Christ to talk to other churches of Jesus Christ, and to recognise each other as such.

\section{The 'Appeal to all Christian People' and the Chicago-Lambeth Quadrilateral}

\section{a Defining the Basis of Faith}

As we have already noted, the goal of the Appeal as stated in its opening paragraph, was to advocate a model of unity as 'an outward, visible, and united society, holding one faith, having its own recognized officers, using God-given means of grace, and inspiring all its members to the world-wide service of the Kingdom of God'.48 In expounding what was meant by 'holding one faith, having its own recognized officers, [and] using God-given means of grace', the

understandings of unity in the Faith and Order movement at this time, see Günther Gassmann, Konzeptionen der Einheit in der Bewegung für Glauben und Kirchenverfassung, 1910-1937 (Göttingen: Vandenhoeck \& Ruprecht, 1979), who points to the centrality of Anglican approaches to unity as expressed in the Lambeth Quadrilateral.

46 Erin M. Brigham, Sustaining the Hope for Unity: Ecumenical Dialogue in a Postmodern World (Collegeville, MN: Liturgical Press, 2012), p. 89.

47 'Meissen Agreement', 17.A.i.

48 'Appeal to All Christian People', LC 1920, Resolution 9.I. 
Appeal offered a revised form of the Chicago-Lambeth Quadrilateral as affirmed by the 1888 Lambeth Conference:

We believe that the visible unity of the Church will be found to involve the wholehearted acceptance of: The Holy Scriptures, as the record of God's revelation of himself to man, and as being the rule and ultimate standard of faith; and the Creed commonly called Nicene, as the sufficient statement of the Christian faith, and either it or the Apostles' Creed as the baptismal confession of belief; the divinely instituted sacraments of Baptism and the Holy Communion, as expressing for all the corporate life of the whole fellowship in and with Christ; a ministry acknowledged by every part of the Church as possessing not only the inward call of the Spirit, but also the commission of Christ and the authority of the whole body ${ }^{49}$

The Appeal's summary of the basis for unity can be compared with the text of the Quadrilateral as agreed by the 1888 Lambeth Conference:

That, in the opinion of this Conference, the following articles supply a basis on which approach may be by God's blessing made towards home reunion:

a. The Holy Scriptures of the Old and New Testaments, as 'containing all things necessary to salvation,' and as being the rule and ultimate standard of faith.

b. The Apostles' Creed, as the baptismal symbol; and the Nicene Creed, as the sufficient statement of the Christian faith.

c. The two sacraments ordained by Christ himself - Baptism and the Supper of the Lord - ministered with unfailing use of Christ's words of institution, and of the elements ordained by him.

d. The historic episcopate, locally adapted in the methods of its administration to the varying needs of the nations and peoples called of God into the unity of his Church. ${ }^{50}$

It is readily apparent that the summary included in the Appeal represents a light revision of the first three articles of the Lambeth Quadrilateral, but

49 'Appeal to All Christian People', LC 1920, Resolution 9.VI.

50 LC 1888, Resolution 11. For its development and background, see Mark Chapman, 'William Reed Huntington, American Catholicity, and the Chicago-Lambeth Quadrilateral', in Avis and Guyer (eds), The Lambeth Conference, pp. 84-106. 
a much more radical revision of the fourth article, witnessing to the intense discussions of episcopacy both in the sub-committee for reunion with nonepiscopal churches and the full committee for reunion, and the tensions around episcopacy that were already emerging in the wider ecumenical movement. ${ }^{51}$

In the documents collected by George Bell, the first three articles of the Lambeth Quadrilateral frequently emerged as a summary of the basis for doctrinal agreement. ${ }^{52} \mathrm{~A}$ rather cautious 'Memorandum' was issued in July 1919 by 137 Church of England clergy. Although it argued that 'Episcopacy is demanded both by history and by the needs of Ultimate Unity, and is the only practical basis of Reunion and Reconstruction', and concluded that 'the Ministry and Sacraments of Non-Episcopal Churches are not inoperative as means of grace, but irregular from the point of view of historic Catholic order, ${ }^{53}$ this Memorandum nonetheless recognised 'that those organised Christian Communions which accept the first three Articles of the Lambeth Statement, but which are in our view deficient in Order through not having retained the Historic Episcopate, are nevertheless true parts of the one Church of Jesus Christ' and that 'their Ministry, in and for their own Communions, is a true Ministry of the Word and Sacraments', adding 'and we acknowledge with reverence and gratitude the operation of the Holy Spirit among them, and in their Ministry. ${ }^{54}$ As seen above, a similar affirmation was integral to the Appeal; here the point is the Memorandum's reference to 'the first three Articles of the Lambeth Statement'. Similarly, in a letter to The Times on 30 August 1919, a group of Free Church clergy, including P. T. Forsyth, J. Scott Lidgett, and J. H. Shakespeare, observed that the Bishop of Norwich had 'advocated the interchange of pulpits between ministers of the Church of England and the Evangelical Free Churches at the "usual normal worship" ... under carefully specified conditions' including 'assent to the first three articles of the Lambeth Quadrilateral.'55 The 'Resolutions on Inter-Communion' signed by 150 Church of England clergy in January 1920 affirmed: '[I]t is our duty to admit to Holy Communion baptised

51 The debates around episcopacy which emerge from the documents collected by Bell are considered in Charlotte Methuen, 'The Kikuyu proposals in their contemporary ecumenical perspective', in Jeremy Bonner and Mark Chapman (eds), Costly Communion: Ecumenical Initiative and Sacramental Strife in the Anglican Communion (Leiden: Brill, 2019), pp. 145-162, and eadem, "An adventure of goodwill and still more of faith."

These texts are discussed in greater detail in Methuen, "The Kikuyu proposals in their contemporary ecumenical perspective'. The Kikuyu proposals were unusual in not being based directly on the Lambeth Quadrilateral.

53 Documents (1916-1920), pp. 68-9.

54 Documents (1916-1920), pp. 68-9.

55 Documents (1916-1920), p. 72. 
and communicant members of other Christian Churches which accept the first three conditions of the Lambeth Statement (1888) who may desire to communicate with us' and saw 'no ground in principle' why this invitation should not be reciprocal. ${ }^{56}$ These texts, all of which were rooted in the English context, all referred explicitly to the Lambeth Quadrilateral, but further afield, the common ground upon which the South India proposals were to be built included agreement on the fundamental nature of Scripture, the creeds and the two sacraments, that is, agreement on articles 1-3 of the Lambeth Quadrilateral, as well as affirmation of the historical episcopate and of the spiritual equality of every member. ${ }^{57}$

Vannerley suggests, however, that 'an important feature of the Reunion Committee's thinking was a growing concern that the Chicago-Lambeth Quadrilateral had outlived its usefulness', and that both Bell and Lang were concerned that the Quadrilateral presented an obstacle to the Free Churches. ${ }^{58}$ Certainly, when Cosmo Gordon Lang, Archbishop of York, who chaired the Reunion Committee, introduced the work of the Committee to the conference on its first working day, $6 \mathrm{July}$, he identified three fundamental aspects of unity: 'There must be these title deeds (a) Common Faith, Nicene Creed ... (b) Common Sacraments (c) Common Ministry which stands for whole Church.59 These points reflect, but do not replicate, the Lambeth Quadrilateral. Responding to Lang's address, Bishop Henson of Durham, referring to the articles of the Lambeth Quadrilateral, remarked 'We rejoice at [the] first three's acceptability', that is, at the acceptance that they had found in ecumenical discussions; the fourth, he thought, should be 'replaced, or at least interpreted, by [the] 19th \& 23 rd Article[s of the Thirty-Nine Articles]. ${ }^{\prime 6}$ In the responses to the question,

$56 \quad$ Documents (1916-1920), p. 77 .

57 Documents (1916-1920), pp. 33-34.

58 Vannerley, 'The Church's One Foundation', pp. 120, 132. Unfortunately Vannerley adduces no evidence for these assertions, but he is presumably referring to concerns about the fourth article.

$59 \quad$ LPL Bell Papers 253, p. 18.

6o LPL Bell Papers 253, p. 23. The relevant articles of the Thirty-Nine Articles are: 19, 'Of the Church. The visible Church of Christ is a congregation of faithful men, in which the pure Word of God is preached, and the Sacraments be duly ministered according to Christ's ordinance, in all those things that of necessity are requisite to the same'; 23, 'Of Ministering in the Congregation. It is not lawful for any man to take upon him the office of public preaching, or ministering the Sacraments in the Congregation, before he be lawfully called, and sent to execute the same. And those we ought to judge lawfully called and sent, which be chosen and called to this work by men who have public authority given unto them in the Congregation, to call and send Ministers into the Lord's vineyard.' Article 19 of the Thirty-Nine Articles is based on Article 7 of the Augsburg Confession: 'Of the 
'What do we consider to be the necessary conditions of Catholic unity as regards Faith, Sacraments and Ministry', put to the opening session of the Committee on Reunion, some bishops referred to the Quadrilateral; they included Chase of Ely and D'Arcy of Armagh. ${ }^{61}$ Henson proposed that the 'basis' of faith should be "[the] Lambeth Q[uadrilateral] with fourth principle revised in way of 19th \& 23rd articles.' ${ }^{2}$ Palmer of Bombay warned: 'Beware of putting forward minima in way of being taken as maxima. This has been done in case of Lambeth Q[adrilateral]. ${ }^{63}$ Bell's notes suggest, however, that while the fourth article was generally regarded as needing revision (as will be discussed in the next section), the bishops' discussion of the basis of faith in fact focused on the Nicene Creed and the sacraments of baptism and the Eucharist, rather than referring explicitly to first three articles of the Quadrilateral. ${ }^{64}$

This focus can be seen in the first draft of the Appeal, in which the four articles of the Quadrilateral were elided into three, taking Scripture and the Nicene creed together as one point, and entirely omitting any reference to the Apostles' creed:

We believe that the visible unity of the Church will be found to involve at least (a) the acceptance of the canonical scriptures of the old and new Testaments as containing all things necessary to salvation, and the Nicene Creed as the sufficient statement of the Christian faith, (b) the acceptance of the two Sacraments of Baptism and the Supper of the Lord, as ordained by Christ Himself, and (c) a common Ministry which possesses the commission of Christ and the authority of the whole

Church. Also they teach that one holy Church is to continue forever. The Church is the congregation of saints, in which the Gospel is rightly taught and the Sacraments are rightly administered. And to the true unity of the Church it is enough to agree concerning the doctrine of the Gospel and the administration of the Sacraments. Nor is it necessary that human traditions, that is, rites or ceremonies, instituted by men, should be everywhere alike. As Paul says: One faith, one Baptism, one God and Father of all, etc. Eph. 4:5-6.' (See http://anglicansonline.org/basics/thirty-nine_articles.html and http://bookofconcord .org/augsburgconfession.php, both accessed 7 March 2020.)

61 LPL Bell Papers 255, fols 14r, 14v,.

62 LPL Bell Papers 255, fol. 18r. Bell has the 19th and 24th articles, but the lack of relevance of the 24th article, taken together with Henson's reference to the 23 rd in the opening debate, suggests that Bell's notes are here incorrect.

63 LPL Bell Papers 255, fol. 15r.

64 See the interventions by D'Arcy, Palmer and Weston, and in a later debate by Charles Gore, retired Bishop of Oxford, who was called as an 'expert witness': LPL Bell Papers 255, fols $14 \mathrm{v}, 15 \mathrm{r}, 16 \mathrm{r}, 23 \mathrm{v}$. 
Body. This Common Ministry, we believe, can only be secured through episcopal ordination. ${ }^{65}$

It was only in the second version of the third draft of the Appeal that this section took on the four-article form of the Lambeth Quadrilateral, effectively implementing Henson's suggestion made in the debate on 12 July. The second draft introduced the clause 'The Holy Scriptures, as the record of God's revelation of Himself to man,' which was retained in the final text of the Appeal. ${ }^{66}$ In the second version of the third draft, the phrase 'and as being the rule and ultimate standard of faith' was added, ${ }^{67}$ together with a reference to the Apostles' creed, as found in the final text. ${ }^{68}$

The formulation of the clause relating to the sacraments also changed significantly during the discussion. A note reporting the voting on the first draft the text indicates that, whilst it had been accepted, some bishops wanted a reference to confirmation to be included. ${ }^{69}$ However, although the second draft amplified the first, it did so by adding an affirmation of the need for supplementary liturgical provision to complement the Book of Common Prayer:

The corporate life of the whole fellowship as expressed for all in the divinely instituted sacraments of Baptism (normally completed in the laying on of hands) and the Holy Communion, with wide liberty for each group to authorise such additional rites and customs of worship and devotion as are found by experience to minister to its spiritual needs. ${ }^{70}$

This formulation reflected the growing sense in the Church of England and across elsewhere in the Anglican Communion, that the Book of Common

65 Methuen, 'Lambeth 1920', pp. 554-555 (Text A); Vannerley, 'The Church's One Foundation', pp. 240-241 (Texts D1 and D2).

66 Methuen, 'Lambeth 1920', p. 554 (Text B); Vannerley, 'The Church's One Foundation', p. 240 (Text $\left.\mathrm{D}_{3}\right)$.

67 Methuen, 'Lambeth 1920', p. 554 (Text C2); Vannerley, 'The Church's One Foundation', p. 240 (Text D4).

68 Methuen, 'Lambeth 1920', p. 555 (Text C2); Vannerley, 'The Church's One Foundation', p. 241 (Text D6).

69 Methuen, 'Lambeth 1920', p. 555 (Text A2); Vannerley, 'The Church's One Foundation', p. 240-241 (Text D2).

70 Methuen, 'Lambeth 1920', pp. 554-555 (Texts B and C); Vannerley, 'The Church's One Foundation', p. 241 (Text $\mathrm{D}_{3}$ ). Text $\mathrm{C}$ removes the interpolation 'normally completed in the laying on of hands'. 
Prayer might require some complementary liturgical provision. ${ }^{71}$ However, the openness expressed in this redaction seems to have been seen as a step too far, and the text was subsequently shortened and simplified, although it retained the understanding that the sacraments provide the foundation for the church's corporate life: 'The corporate life of the whole fellowship as expressed for all in the divinely instituted sacraments of Baptism and the Holy Communion. ${ }^{72}$ The final version simply reordered this text: "The divinely instituted sacraments of Baptism and the Holy Communion, as expressing for all the corporate life of the whole fellowship in and with Christ. ${ }^{73}$ The end result of this process was a statement of the basis of faith which was closely aligned to the first three articles of the Lambeth Quadrilateral. A similar affirmation has formed the basis of most agreed statements of faith in ecumenical agreements involving Anglicans. ${ }^{74}$

\section{b Ministry, Episcopacy, and Unity}

The formulation of the fourth article, concerning the ministry, and in particular the episcopate, deviated much more significantly from the Lambeth Quadrilateral. Its formulation changed little in the course of the redactions. The first draft, 'a common Ministry which possesses the commission of Christ and the authority of the whole Body'75 was amended in the next version to 'a Ministry which will be accepted [later changed to acknowledged] by every part of the Church, as possessing the commission of Christ and the authority of the whole

71 For discussions of Prayer Book reform in England before, during and after the First World War, see Dan D. Cruickshank, The Theology and Ecclesiology of the Prayer Book Crisis, 19061928 (Cham: Palgrave MacMillan, 2019). The conviction that the Book of Common Prayer might not provide adequate provision for all circumstances was also expressed at the 1920 Lambeth Conference by the Committee on Missionary Problems, LC 1920, Resolution 36: 'While maintaining the authority of the Book of Common Prayer as the Anglican standard of doctrine and practice, we consider that liturgical uniformity should not be regarded as a necessity throughout the Churches of the Anglican Communion. The conditions of the Church in many parts of the mission field render inapplicable the retention of that Book as the one fixed liturgical model.'

72 Vannerley, 'The Church's One Foundation', p. 241 (Texts D4 and D5).

73 Methuen, 'Lambeth 1920', p. 555 (Text C2); Vannerley, 'The Church's One Foundation', p. 241 (Text D6).

74 Examples include the Meissen, Fetter Lane, Reuilly and Porvoo Agreements, the Anglican-Methodist Covenant, the Porvoo Agreement, Called to Common Mission, and the Waterloo Agreement.

75 Methuen, 'Lambeth 1920', pp. 554-555 (Text A); Vannerley, 'The Church's One Foundation', p. 241 (Texts D1 and D2). 
Body' ${ }^{\prime}$ It was once again in the second version of the third draft that the bishops settled on their final formulation about ministry, adding in a reference to a sense of vocation: 'A ministry acknowledged by every part of the Church as possessing not only the inward call of the Spirit, but also the commission of Christ and the authority of the whole body. ${ }^{\prime 7}$

From the first draft onwards, this definition of ministry was followed by the caveat that this ministry could 'only be secured through episcopal ordination. ${ }^{78}$ The second redaction added an explanation: 'In view of the position of episcopacy in the past history and present life of the Church, we believe that this common ministry is to be secured through episcopal ordinations. ${ }^{79}$ The second draft strengthened this affirmation: 'Considerations alike of history and of present experience point to the Episcopate as the one means of providing such a ministry.' ${ }^{\prime 80}$ Draft $\mathrm{C}$ reformulated this caveat as a question: 'May we not reasonably claim that considerations alike of history and of present experience point to the Episcopate as the as the one means of providing such a ministry?'81 In the final version, this question was moved to the beginning of the following section, which considered the role of episcopacy.

The first draft of the Appeal also included an affirmation of the importance of the episcopate as a basis for unity, which was accepted with four dissensions: 'We believe that the acceptance of the Historic Episcopate would not only secure for the whole Church a common Ministry, but also prove in the future, as in the past, to be a powerful means of maintaining the Unity and continuity of the Church. ${ }^{82}$ The second draft appended to a slightly amended version of this passage the assertion of the place of the Anglican Communion 'by the side of the ancient episcopal communion of East and West' (as discussed above), but also expressed the bishops' expectation that 'the office of the Bishop should be increasingly [later amended to everywhere] exercised in a representative and constitutional manner in accordance with the ideals of the

76 Methuen, 'Lambeth 1920', p. 555 (Text A2); Vannerley, 'The Church's One Foundation', p. 241 (Texts $\mathrm{D}_{3}$ and $\mathrm{D}_{4}$ ).

77 Methuen, 'Lambeth 1920', p. 555 (Text C2); Vannerley, 'The Church's One Foundation', p. 241 (Text D6).

78 Methuen, 'Lambeth 1920', pp. 554-555 (Text A); Vannerley, 'The Church's One Foundation', p. 241 (Texts D1 and D2).

79 Methuen, 'Lambeth 1920', p. 555 (Text A2).

8o Methuen, 'Lambeth 1920', p. 555 (Text B); Vannerley, 'The Church's One Foundation', p. 241 (Texts $\left.\mathrm{D}_{3}, \mathrm{D}_{4}, \mathrm{D}_{5}\right)$.

81 Methuen, 'Lambeth 1920', p. 555 (Text C).

82 Methuen, 'Lambeth 1920', p. 556 (Text A); Vannerley, 'The Church's One Foundation', p. 241 (Texts D1 and D2). 
early and undivided Church.83 This call for the exercise of the episcopate in a 'representative and constitutional manner' reflected the synodical structures of the Protestant Episcopal Church of the USA (today The Episcopal Church) and the recent provision of representative forms of government for the Church of England. ${ }^{84}$ These developments were also reflected in a further resolution from the Committee for Reunion, which recommended that 'every branch of the Anglican Communion should develop the constitutional government of the Church and make fuller use of the capacities of its members for service', 85 The formulation in the Appeal also responded to a concern that, as Weston put it in the discussion, the "English episcopate does not represent [the] fatherhood of God, ${ }^{86}$ recognising that, particularly in England, 'episcopacy was seen as inseparable from prelacy and the state role of the Anglican bishops'. ${ }^{87}$ The emphasis on a constitutional exercise of the episcopate was intended to express 'all that ought to be involved for the life of the Christian family in the title of Father-in-God', 88

The third draft related the acceptance of the episcopate to the future unity of the church:

[W]e eagerly look forward to the day when through its acceptance in the whole Church we may unitedly share in the gifts of the Spirit pledged to the whole body in the apostolic rite of the laying-on of hands, and in the joy and fellowship of a Eucharist in which as one Fellowship we may together, without any doubtfulness of mind, offer to the one Lord our worship and service. ${ }^{89}$

With light amendments, this passage was incorporated into the text of the Appeal. The final version of this paragraph (VII in the final text) opened with the caveat question about episcopacy, affirmed the 'spiritual reality' of the ministry of non-episcopal churches, and the need for the 'constitutional' exercise of episcopacy, and closed with this declaration, which implied that the acceptance

83 Methuen, 'Lambeth 1920', pp. 555-556 (Text B); Vannerley, 'The Church's One Foundation', p. 241 (Texts $\left.\mathrm{D}_{3}, \mathrm{D}_{4}, \mathrm{D}_{5}\right)$.

84 See Methuen, 'An adventure of goodwill and still more of faith.'

85 LC 1920, Resolution 14.

86 LPL Bell Papers 253, pp. 24-25.

87 Vannerley, 'The Church's One Foundation', 133.

88 'Appeal to All Christian People', LC 1920, Resolution 9.VII.

89 Methuen, 'Lambeth 1920', p. 556 (Text C). Lightly amended, this was included in the final text: Methuen, 'Lambeth 1920', p. 556 (Text C2); Vannerley 'The Church's One Foundation', p. 241 (Texts D6). 
of episcopacy was necessary if eucharists were not to be 'doubtful. ${ }^{90}$ In the final text of the Appeal, this paragraph was followed directly by the bishops' solemn commitment to accept from other churches 'a form of commission or recognition which would commend our ministry to their congregations' and an expression of their hope that ministers not episcopally ordained would accept such a commission through episcopal ordination. ${ }^{91}$ By making such a move, the bishops asserted, 'no one of us could possibly be taken to repudiate his past ministry. God forbid that any man should repudiate a past experience rich in spiritual blessings for himself and others. ${ }^{92}$

Paragraphs VI, VII and VIII of the Appeal thus sent mixed messages, strongly affirming the spiritual reality of ministry in non-episcopal churches, but also intimating that the sacraments of non-episcopal churches could be seen as 'doubtful'. Earlier drafts of the Appeal included an introductory section to paragraph VIII which emphasised the different gifts found in the different churches, but which was not included in the final text:

We want this, and all other ministries of grace, to be available for the whole Fellowship. For there are diversities of gifts, but the same Spirit. There are differences of ministries, but the same Lord. We desire to share the gifts and inheritances of Grace held in trust by the other groups. It is GOD's will that they should operate freely within the one body..$^{93}$

Here too though, the formulation 'this, and all other ministries of grace' again pointed, in its context, towards the necessity of episcopacy.

It can be seen, therefore, that paragraphs VII and VIII of the Appeal provided a counterweight to the Appeal's affirmations of the giftedness of all churches and the Spirit-filled nature of their ministries. This impression was heightened by the guidelines which accompanied the Appeal as Resolution 12, which, in the context of setting out what Anglican bishops might allow whilst a 'definite scheme of union' was being drawn up, alluded to the 'irregularity of admitting to Communion the baptized but unconfirmed communicants of the non-episcopal congregations. ${ }^{94}$ The ambiguity within the Appeal on this point

9o 'Appeal to All Christian People', LC 1920, Resolution 9.vir.

91 'Appeal to All Christian People', LC 1920, Resolution 9.VIII.

92 'Appeal to All Christian People', LC 1920, Resolution 9.VIII.

93 Methuen, 'Lambeth 1920', p. $55^{6}$ (Text C). For an earlier form of this passage, see also Methuen, 'Lambeth 1920', p. 556 (Text B2); Vannerley, 'The Church's One Foundation', p. 242 (Text D3). 
reflects an unresolved debate during its drafting as to the nature of episcopacy and its role in a united church.

The tension between Anglican insistence on the essential role of episcopacy and a wish to affirm the ministries of other churches was already apparent in Archbishop Lang's opening address to the conference. Setting out the questions to be considered by the Reunion Committee, Lang argued that 'Episcopacy must be decided, not tolerated.' While he did not believe that Anglicans should 'insist on a Tractarian view of apostolic succession', he was also 'not impressed by [the] proposal of permanent moderators, later Bishops'. He asked whether it would be possible to 'acknowledge [the] place of non-episcopal churches in the great Church' and to 'pronounce positively on value of other ministries in God's sight', asserting that episcopal ordination would 'not repudiate their ministry but add the valid mark. ${ }^{95}$ This tension was also evident in the formulation of the remaining two questions put before the bishops: 'What do we regard as the sufficient principle justifying any claim that the ministry of a united church should be based upon episcopal ordination? What attitude ought we to take as to the "validity" of the orders and sacraments of the nonepiscopal churches?' The bishops' responses to these questions were varied. There were some who did not view episcopacy as essential for the church. Thus, Winfrid Burrows, Bishop of Chichester, took the view that, though there was 'nothing vital about episcopacy', 'we must have ministers (as Christ did) and they must be commissioned by men of note. ${ }^{96}$ Henson, while he maintained that there was 'no question of abandoning episcopacy', asked whether it was 'to be treated as exclusive'. He suggested that 'it could only be imposed as indispensable if proved as ordered by Christ. ${ }^{97}$ Henson's proposal was that presbyterian orders should be recognised by Anglicans, as a 'half way house to Reunion'; 'ultimate union' must however be on the 'basis of [the] episcopate. ${ }^{98}$ D'Arcy did not think the Lambeth Conference had the authority to 'accept the non-episcopal orders as valid by vote'. He also warned against trying to discuss episcopacy in the abstract, away from the 'concrete life of [the] church', and suggested that if the Church were united 'the Church could do anything she chose to do - c[oul]d e.g. get rid of episcopacy (which after all was [a] case of survival of fittest, not a matter of right revelation or order) \& create something else'. In his view, 'orders are conferred, not by individual Bishop, but by whole church acting through him, and hence by Christ' and he argued that if a group

95 LPL Bell Papers 253, p. 18.

$96 \quad$ LPL Bell Papers 253, p. 22.

$97 \quad$ LPL Bell Papers 253, p. 23.

98 LPL Bell Papers 255, fol. 18r. 
of people were shipwrecked on a desert island hey would be 'competent ... to ordain and administer sacraments, as [a] community' ${ }^{\prime 9}$

In contrast, Weston regarded episcopacy as necessary 'because the present order of the universal church requires it, a large majority of Christians require it and in no other way w[oul]d we get in with [the] historic Churches of E[ast] \& W[est].' He argued that this was a question of securing apostolic order: 'it won't be seriously denied from [the] beginning [the] church has been ruled by some persons to whom authority was committed by $\mathrm{O}[\mathrm{ur}] \mathrm{L}$ [ord]'; this was the means by which 'the apostolic privilege and power' was handed on, and 'In the apostolic fellowship men had to be in communion with the persons to whom this authority was committed, as witnesses and pastors.' However, Weston did concede that 'it does not matter whether the persons were B[isho]ps or Presbyters, superintendents. ${ }^{100}$ Armitage Robinson, Dean of Wells, who was called like Charles Gore as an 'expert witness' to contribute to the debate on 14 July, maintained that episcopacy 'is historically proved [to be] of apostolic origin, hence a gift of God'; that 'history shows its effectiveness for unity in doctrine \& organisation' and that it is the 'only possible basis for unity with Rome \& [the] East'. ${ }^{101}$ Another 'expert witness', Herbert Ryle, Dean of Westminster, previously bishop successively of Exeter and of Winchester, concurred, opining that 'In view of Eastern possibilities, episcopacy with its historic character and in [the] best interests of practical gov[ernmen]t is indispensable.' It was, he suggested 'far older than [the] divisions of Xnty'. Ryle maintained that this view 'w[oul]d not unchurch the Noncon[formist]s'. Indeed, he claimed, 'In their hearts Noncon[formist] leaders probably believe episcopacy [to be] the basis. ${ }^{102}$ Weston's and Ryle's comments illustrate many of the Anglican bishops' profound lack of understanding of the underlying theology of churches with polities which were not episcopal. It is not surprising that responses to the Appeal often read it as a call for submission by non-episcopal churches. ${ }^{103}$

As several bishops recognised, Lang's questions had in effect prompted discussion about whether episcopacy was to be considered as of the esse (the being) of the church, or as of the bene esse (the well-being) of the church. Palmer viewed this distinction as valuable in theory but not in practice, for, he argued:

\footnotetext{
99 LPL Bell Papers 255, fol. 14V-15r.

100 LPL Bell Papers 255, fols 16v-17r.

101 LPL Bell Papers 255, fols 24r-v.

102 LPL Bell Papers 255, fol. 24r.

103 See for contrasting responses by Norman MacLean, James Cooper and Dugald MacFadyen, Methuen, 'Lambeth 1920', p. 532; eadem, 'An adventure of goodwill and still more of faith'.
} 
'If we are told something is bene esse we must go for it.'104 Henson saw the distinction as valid and useful 'particularly in view of our attitude to non episcopal churches;' 105 presumably because it would make possible the 'half way house' of recognising presbyterian orders. Clearly the ambiguity manifested in the Appeal replicated the bishops' own disagreement about the nature of the episcopacy and its significance for establishing the unity of the church.

The question of the recognition of orders was similarly vexed, although it is apparent from Bell's notes that the idea that there should be a mutual giving and receiving of authorisation by those joining in a united church was felt to be a breakthrough. Palmer affirmed:

If the only thing which stood between Rome and England was ordination I w[oul]d willingly be reordained ... I would not care in the least if people said that such action on my part involved confession of invalidity on my part. I should know to the contrary. Again I am willing to submit to ordination by Moravians if they will take one in this for me. ${ }^{106}$

For Weston the question of ordination was closely related to the question of who could minister with authority in a particular ecclesiastical context. In a statement hypothetically addressed to ministers who were not episcopally ordained, he observed:

I have no attitude whatever to your orders ... But I want this - I want you to do this [i.e. to preside at the Eucharist] with authority accepted by my congregation, and I will give it to you - I [will] receive [the] same from you. I don't deny your ministry. I ask you to acknowledge [the] simple fact that you have not in eyes of my congregation authority. ${ }^{107}$

D'Arcy argued that the bishops should 'keep [the] question of validity open', recognising that if an agreement with the presbyterian church could be reached, 'with episcopacy, leading ultimately to organic union', this would result in 'a certain remnant of presbyters not in [the] $\mathrm{Ch}$ [urch] of $\mathrm{E}$ [ngland]'; so he suggested that 'they c[oul]d be - the few - possibly recognised - in view of the purpose or end achieved.. 108

\footnotetext{
104 LPL Bell Papers 255, fol. $15 \mathrm{~V}$.

105 LPL Bell Papers 255, fol. 16r.

106 LPL Bell Papers 255, fol. 15v.

107 LPL Bell Papers 255, fols 17r-v.

108 LPL Bell Papers 255, fols 14V-15r.
} 
The bishops' discussions in 1920 thus presage the difficult debates about episcopacy that have continued to trouble Anglican ecumenical dialogues, particularly with Presbyterian and Methodist churches. It was disagreements over episcopacy and ordination that caused the Church of England's negotiations with the English Free Churches to collapse in the late 1920s. ${ }^{109}$ Similar disagreements led to the rejection of the Church of England-Methodist Church proposals in the early 1970s, ended the Scottish Church Initiative For Union (SCIFU) proposals in Scotland in 2003 and are currently under debate in the attempts to move from the Anglican-Methodist Covenant to a relationship of ecclesial communion between the Methodist Church of Great Britain and the Church of England. ${ }^{110}$ Moreover, the Church of South India had to exist outwith the structures of the Anglican Communion for decades after this united church was established. Current dialogues, although they generally identify full visible unity as their aim, have tended to avoid attempting to produce a structurally united church. The final short section of this article returns to the Appeal's understanding of organic unity and reads it in the context of other resolutions passed at the 1920 Lambeth Conference.

\section{III \\ The 'Appeal to all Christian People' in the context of the 1920 Lambeth Conference}

Although the 'Appeal to all Christian People' is probably the most extensively discussed resolution to emerge from the 1920 Lambeth Conference, it was just one of eighty total, including further resolutions proposed by the sub-committee for reunion with episcopal churches as well as resolutions proposed by the other committees, some of which also illustrate the bishop'

109 See Vannerley, 'The Church's One Foundation', pp. 166-177; compare Healing the past Building the future: The report of the Church of England-United Reformed Church joint study group on God's Reign and Our Unity, pp. 5-6 (online at. https://urc.org.uk/what_we_do/ ecumenical/docs/healing_the_past_building_the_future.pdf; accessed 10 March 2020).

110 For SCIFU, see Sheilagh M Kesting, 'Being Ecumenical in Scotland Today', Theology in Scotland 13/2 (2006), pp. 5-16 (online at: https://ojs.st-andrews.ac.uk/index.php/TIS/arti cle/view/140, accessed 20 March 2020). For Anglican-Methodist relations in the 1950s and 196os, see An Anglican-Methodist Covenant: Common Statement of the Formal Conversations between the Methodist Church of Great Britain and the Church of England (Peterborough: Methodist Publishing House, 2001), pp. 19-22. Documents relating to the current discussions between the Church of England and the Methodist Church of Great Britain can be found here: http://www.anglican-methodist.org.uk/ (accessed 10 March 2020). Compare also Miriam Haar, 'Apostolicity: Unresolved Issues in Anglican-Methodist Dialogue', Ecclesiology 9 (2013), pp. 39-65. 
understanding of ecclesial unity. Read together with the Appeal, these resolutions suggest that the vision of organic unity was much less important to the Anglican bishops than the Appeal might seem to suggest. Of particular note are the other resolutions on Reunion, those arising from the committee on missionary problems, and those relating to the Anglican Communion.

The Appeal's vision of organic unity as an ultimate aim was complemented by another resolution emerging from the Committee on Reunion which called for the formation of 'councils representing all Christian Communions' to be formed to prove 'centres of united effort to promote the physical, moral, and social welfare of the people, and the extension of the rule of Christ among all nations and over every region of human life.'111 This step towards a conciliar approach to ecumenical cooperation was not discussed in the Appeal, and it is unclear how it was intended to relate to the aim of organic unity.

In addition, the remaining resolutions on Reunion, all of which related to episcopal churches, show little evidence of the commitment to organic union articulated in the Appeal. The resolution on the Moravian Church, or Unitas Fratrum, even represented a step back from commitments that had been made at the 1908 Lambeth Conference. ${ }^{112}$ The affirmation of what was in practice a relationship of communion with the Church of Sweden recommended mutual eucharistic hospitality and pulpit exchange, and provided for the participation of Anglican bishops in the consecration of Swedish bishops, without making any provision to deepen this relationship or to develop shared structures. ${ }^{113}$ This would continue to be the pattern for Anglican relationships with other churches, particularly, but not only, where the churches were based in largely separate geographical territories. The underlying approach taken by the remaining ecumenical resolutions therefore seems to be more in line with what the bishops had defined as a federal approach than with the vision of organic unity. Indeed, the 1920 Lambeth Conference to some extent presaged the debates between conciliar approaches to unity and organic unity that would emerge in the World Council of Churches after the Second World War. ${ }^{114}$ There

\footnotetext{
111 LC 1920, Resolution 13.

112 LC 1920, Resolution 29. A century later the agreement of communion proposed by the 1908 Lambeth Conference has been achieved only in the USA. The Fetter Lane Agreement in England is a Meissen-type agreement, which does not achieve interchangeability of ministries.

113 LC 1920, Resolutions 24 and 25. This relationship forms an important precursor to the Porvoo Agreement.

114 See, for instance, Brigham, Sustaining the Hope for Unity, pp. 87-98; Miriam Haar, "The Struggle for an Organic, Conciliar and Diverse Church: Models of Church Unity in Earlier Stages of the Ecumenical Dialogue', in Gesa Elsbeth Thiessen (ed.), Ecumenical
} 
are similarities here to the understanding of unity as reconciled diversity which underpins the Leuenberg Concord of 1973 and the resulting Community of Protestant Churches in Europe. At the same time, the agreement with the Church of Sweden already illustrates the attention to the question of how to reconcile structures of episcope (oversight) as a presupposition for the interchangeability of ministries which is characteristic of Anglican relationships of communion and which goes beyond the requirements of Leuenberg. ${ }^{115}$

The resolutions relating to missionary problems also show the bishops grappling with questions of unity. For instance, the bishops resolved that the normal method of missions is that in which the whole Church, within any area, acts as a missionary body expressly organised for that function' (although they did not define what was meant here by 'Church'), and they emphasised that missionary societies 'should not stand outside the one organisation, but should be elements in it'.116 The aim must be to establish 'self-governing, selfsupporting, and self-extending Churches'.117 Moreover, although the bishops recognised that 'difference of race and language sometimes requires that provision should be made in a province for freedom of development of races side by side', so that episcopal structures might not always be territorial, they emphasised that the 'ideal of the one Church should never be obscured'.118 In these resolutions, the approach seems much more akin to one of organic unity, highlighting the extent to which the Appeal was shaped by the concerns arising from the mission field.

Finally, the resolutions on the Anglican Communion illustrate the complexities of defining the Appeal's stated aim of 'an outward, visible, and united society'. The 1920 Lambeth Conference encouraged the formation of Anglican churches (provinces) each made up of at least four dioceses. Despite the calls from the Committee for Reunion for a constitutionally exercised episcopate, the only structure that was required for the establishment of a province was a

ecclesiology: unity, diversity and otherness in a fragmented world (London: T\&T Clark, 2009), pp. 49-61.

115 In the Leuenberg Concord, mutual recognition of orders follows from the declaration of altar and table fellowship: §33.c 'they accord each other table and pulpit fellowship; this includes the mutual recognition of ordination and the freedom to provide for intercelebration': https://www.ekd.de/en/Leuenberg-Agreement-304.htm (accessed 8 March 2020). See also the discussions in Michael Weinrich, Ulrich Möller, Vicco von Bülow, and Heike Koch (eds), Kirchen in Gemeinschaft - Kirchengemeinschaft?: Impulse der Leuenberger Konkordie für die ökumenische Zukunft (Neukirchen-Vluyn: Neukirchener Theologie, 2014), especially the articles by Friedrich Weber and Michael Welker.

116 LC 1920, Resolution 33 .

117 LC 1920, Resolution 34.

118 LC 1920, Resolution 35 . 
House of Bishops, though such a 'newly constituted synod of bishops' was expected to 'proceed as soon as possible to associate with itself in some official way the clergy and laity of the province'. Moreover, it was provided that 'each national and regional Church will determine its own constitutional and canonical enactments.'19 Although the Consultative Body set up by the 1897 Lambeth Conference was 'framed so as to represent all branches of the Anglican Communion', it was emphatically defined to be 'a purely advisory body' which 'offers advice only when advice is asked for'. ${ }^{120}$ Similarly, as the Encyclical observed, the Lambeth Conference 'does not claim to exercise any powers of control or command.' ${ }^{121}$ The churches (or provinces) of the Anglican Communion, it insisted, 'are indeed independent, but independent with the Christian freedom which recognises the restraints of truth and live. They are not free to deny the truth. They are not free to ignore the fellowship.'122 These provisions leave open the question of how the bishops of the Anglican Communion thought 'an outward, visible, and united society', as defined by the Appeal, should actually be constituted.

A final vision of unity appeared in the Encyclical Letter. This focused on 'Fellowship' as the 'one idea' that 'runs through all our work in the Conference, binding it together in a true unity'.123 This language was applied to the work of all committees, but the summary of the work on international relations bore a striking similarity to the language of the Appeal: "[T] he purpose of God for the nations, as we conceive it, is that they should form a fellowship, as of a brotherhood or a family. They are intended as nations by love to serve one another. They are intended to develop distinctive gifts and characters, and to contribute them to the common good.124 The Encyclical affirmed that 'within redeemed humanity nations will not cease to exist, but nationality itself will be redeemed.' ${ }^{125}$ That redemption too was to be understood in terms of fellowship:

Each of us belongs by his birth to some one of the many nations of the world. But every Christian belongs by his second birth to one holy nation, which is God's own possession. When loyalty to his own nation comes into conflict with loyalty to that holy nation of which Christ is king, a

\footnotetext{
119 LC 1920, Resolution 43.

120 LC 1920, Resolution 44.

121 LC 1920 Encyclical, p. 14.

122 LC 1920 Encyclical, p. 14.

123 LC 1920 Encyclical, p. 9.

124 LC 1920 Encyclical, p. 19.

125 LC 1920 Encyclical, p. 19.
} 
Christian can have no doubt which loyalty must give way ... No selfishness in the world has been so persistent or so ruthless as national selfishness, it is to save men from such wickedness that Jesus Christ binds them together into one holy nation. In the fellowship of this great unity, nationality finds its redemption: while national characteristics are preserved for noble use and mutual benefit. But the love of God encompasses all and reconciles men and nations in the brotherhood of redeemed humanity. ${ }^{126}$

This vision of fellowship amongst nations resonated strongly with the vision of the Appeal, although the emphasis on the continued existence of nations highlighted a challenge which Palmer had identified but which the Appeal did not address: the extent to which the reunited church would be national and the question of how national churches could and should relate to each other. ${ }^{127}$ At the same time, the theme of fellowship which permeated the Encyclical also pointed to a deeper conviction: that unity and fellowship were already present in God and needed only to be discovered. Ultimately, the Encyclical affirmed, 'the unity which we seek exists ... the fellowship of the members of the one Body exists. We have only to discover it and to set free its activities.'128 The Appeal's view of unity was in this sense deeply optimistic.

\section{Conclusion}

Much could be said about contemporary responses to the Appeal, which were mixed. While some churches and some commentators applauded it as a significant step forwards, others regarded it as not going far enough, or even as a step backwards. ${ }^{129}$ This article has exposed the ambiguities inherent in the Appeal itself, but also the tensions between the Appeal and other resolutions passed by the 1920 Lambeth Conference, which made such mixed reactions

126 LC 1920 Encyclical, p. 22.

127 The Lambeth Conference 1920 in many ways exemplifies the question which became urgent on the formation of the Church of South: how the world communions, organised on confessional lines, related to the ecumenical initiatives which sought to transcend confessional boundaries. For a discussion of this point see Harding Meyer, 'Christian World Communions: Identity and Ecumenical Calling', Ecumenical Review 46 (1994), pp. 383393; Brigham, Sustaining the Hope for Unity, pp. 99-100.

128 LC 1920 Encyclical, p. 12.

129 For some of these responses, see Methuen, 'Lambeth 1920', pp. 530-533; eadem, 'An adventure of goodwill and still more of faith'; Vannerley, 'The Church's One Foundation', pp. $166-168$. 
inevitable. We have also seen that the Appeal presaged many of the approaches to ecclesial unity which have shaped the last century of ecumenical engagement. Much has changed in that period: in particular, arrangements which a century ago had been deemed unthinkable - in particular attendance at the services of another church, and mutual eucharistic hospitality - now may not even be understood by many Christians to require formal agreement. However, the Appeal's vision of a church brought together in organic unity remains elusive, and for many today it is not even an aim. Early in the discussions of the Reunion Committee, Henson exclaimed, 'Thirty two years since Lambeth Quadrilateral: we must take corporate action. ${ }^{130}$ One hundred years since the 'Appeal to All Christian People,' there is no question that much has been achieved, but there is still much to be done.

130 LPL Bell Papers 253, p. 23. 